\title{
COVID-19 Vaccinations and the Right to Health in Indonesia: Social Justice Analysis
}

\author{
Muhammad Rafliansah Aziz* \\ University of Indonesia, Indonesia \\ Muhammad Alfitras Tavares \\ University of Indonesia, Indonesia \\ Chalisa Jasmine Azhima \\ University of Indonesia, Indonesia
}

\begin{abstract}
While the COVID-19 pandemic is far from the end, vaccinations have become an inevitable alternative in combating this pandemic. According to the WHO, COVID-19 vaccines are considered public goods. Consequently, they should be distributed equally to the citizens as the fulfillment of the right to health. This study aimed to analyze how COVID-19 vaccinations in Indonesia have been practiced. Also, it examined the government's responsibility to ensure that COVID-19 vaccines are distributed equally in reflecting distributive justice by enquiring to what extent the government's policy on independent vaccination relates to the fulfillment of human rights. This study used a legal research method based on a literature review. This study showed that some aspects of the vaccination are under distributive justice and welfare state. However, the Gotong Royong vaccination policy does not refer to distributive justice and the welfare state, resulting in injustice, discrimination, and economic inequality because it only provides certain privileged citizens access to vaccines. Therefore, the government needs to reconsider the Gotong Royong vaccination, focusing on accelerating the vaccination system for vulnerable individuals and groups.
\end{abstract}

KEYWORDS: COVID-19, Right to Health, Social Justice, Vulnerable Groups.

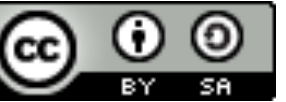

\section{HOW TO CITE:}

Aziz, Muhammad Rafliansah, et al., "COVID-19 Vaccinations and the Right to Health in Indonesia: Social Justice Analysis” (2021) 8:2 Lentera Hukum 211-240. DOI: <https://doi.org/ 10.19184/ejlh. v8i2.23515>.

Submitted: 10/03/2021 Reviewed:05/04/2021 Revised: 01/07/2021 Accepted: 07/07/2021

* Corresponding author's e-mail: muhammad.rafliansah@ui.ac.id 


\section{INTRODUCTION}

The COVID-19 pandemic has been a crucial problem in Indonesia ever since it started. Since the beginning of 2020, the world has been handling the COVID-19 pandemic. ${ }^{1}$ Indonesia confirmed the first COVID-19 case back in March of 2020, ${ }^{2}$ before it has dramatically infected citizens with the amount of up to millions of cases in March 2021. ${ }^{3}$ As the world experienced the devastating effect of a significant outbreak, a race for COVID-19 vaccines began. In January of 2021, the first wave of vaccines arrived in Indonesia and was ready to be distributed. ${ }^{4}$

By June 30, 2021, the total number of reported COVID-19 cases in Indonesia was 2,178,272.5 Even though the government has started the vaccination program in January 2021, new cases are still surging, with an additional dramatic increase to 21,807 reported daily cases on June $30,2021 .^{6}$ Previous studies indicated that developing countries are facing numerous challenges in rolling out their COVID-19 vaccination plans, such as the limited global supply of vaccines to be procured, barriers to the vaccination

1 The COVID-19 pandemic was caused by a strain of coronavirus (the SARS-CoV2). The World Health Organisation (WHO) declared COVID-19 outbreaks as a global pandemic on March 11, 2020. Riyanti Djalante, et al., "Review and analysis of current responses to COVID-19 in Indonesia: Period of January to March 2020" (2020) 6:4 Progress in Disaster Science 1-9.

2 Dewi Nur Aisyah, et al., "A spatial-temporal description of the SARS-CoV-2 infections in Indonesia during the first six months of the outbreak" (2020) 15:12 PLOS ONE 1-14.

3 As of March 4, 2021, the total number of COVID-19 cases in Indonesia is as high as 1,361,098 confirmed cases. Komite Penanganan COVID-19 dan Pemulihan Ekonomi Nasional, "Data Vaksinasi COVID-19 (Update 4 Maret 2021)”, (2021), online: <https://covid19.go.id/p/berita/data-vaksinasi-covid-19-update-4-maret2021>.

4 Sebastian Strangio, "Jokowi Receives First Shot as Indonesia Begins CoronaVac Rollout," (2021), online: The Diplomat <https://thediplomat.com/2021/01/jokowireceives-first-shot-as-indonesia-begins-coronavac-roll-out/>.

5 Haryanti Puspa Sari, "UPDATE: Tambah 21.807 Orang, Kasus Covid-19 Indonesia Capai 2.178.272”, (2021), online: Kompas.com <https://nasional.kompas.com/read/ 2021/06/30/16203191/update-tambah-21807-orang-kasus-covid-19-indonesiacapai-2178272>.

6 Ibid. 
distribution, and limited resources to administer the vaccination. ${ }^{7}$ The Indonesian government has guaranteed the availability of vaccines, by June of 2021, but it has counted 14,3 doses per 100 citizens, much lower than the world average of 37,5 doses per 100 citizens. ${ }^{8}$ Moreover, Indonesia is facing the challenge of distributing vaccines to many remote areas all around the archipelago. $^{9}$

In Indonesia, the COVID-19 vaccination is mainly under the government's control. The control includes regulating the terms and conditions of vaccination, procuring vaccines, and acting as the primary actor of vaccination. However, existing regulations provide private institutions with independent vaccination. Therefore, it has stimulated discourses on the ethical matter against the private sector. Also, it relates to human rights and social justice issues, mainly vaccines as public goods and Indonesia's adherence to the welfare state. To some extent, Indonesia is deemed as a welfare state with a minimal model, where social security and welfare programs are provided sporadically, partially, and minimally. ${ }^{10}$ Indonesia's welfare programs are not as widely implemented as those in Scandinavian countries; welfare programs are universal with a substantial role in providing an extensive social safety net for citizens comprehensively. However, the 1945 Constitution remains to have values called the welfare state with a feature of the government's responsibility to provide basic needs and services for citizens. ${ }^{11}$ Therefore, the Indonesian government should implement laws

7 Abu Baker Sheikh, et al., "COVID-19 vaccination in developing nations: Challenges and opportunities for innovation" (2021) 13:2 Infectious Disease Reports 429-436.

8 BBC News, "Covid: Vaccines running out in poorer nations, WHO says," online: <https:/www.bbc.com/news/world-57558401>.

9 Ratna Puspita, “Kemenkes: Kondisi Geografis Tantangan Distribusi Vaksin”, (2021), online: Republika.co.id <https://www.republika.co.id/berita/qrut99428/ kemenkeskondisi-geografis-tantangan-distribusi-vaksin>.

10 This is because social security is generally only given to civil servants, members of the Armed Forces, and private employees who can afford premiums. Edi Suharto, "Peta dan Dinamika Welfare State Di Beberapa Negara: Pelajaran Apa yang Bisa Dipetik untuk Membangun Indonesia?" (2006) 1-15.

11 Stein Kuhnle \& Sven Hort, "The Developmental Welfare State in Scandinavia Lessons for the Developing World" (2004) 17 Social Policy and Development. 
that adhere to distributive justice, with COVID-19 vaccinations as no exception. ${ }^{12}$

As per the constitution, the government is responsible for fulfilling human rights, including the right to health. ${ }^{13}$ In particular, the 1945 Constitution requires the government to provide basic health services and social security systems for all citizens and empower vulnerable and poor members of society. ${ }^{14}$ Consequently, COVID-19 vaccines, which essentially are public goods, have to be distributed justly to ensure human rights and social justice. ${ }^{15}$ The government's responsibility to justly distribute COVID-19 vaccines is the consequence of Indonesia's adherence to the welfare state.

However, the Indonesian government's independent vaccination has raised concern on how the policy could potentially lead to an unequal distribution of COVID-19 vaccines. The independent vaccination allows a citizen to get vaccinated early, even though they are not part of the priority groups of vaccine recipients. Those members of the society have the privilege to get early vaccinates because they are employees of financially-able corporations that can afford to independently finance a private vaccination service for their employees outside of the government-financed vaccination services. The policy allows paying corporations to vaccinate their employees earlier than other members of society, even priority groups. It has the potential to create a condition where the poor and those that are not part of the corporations involved in the independent vaccination program cannot get the same access to COVID-19 vaccines.

Previous studies lacked the regulatory and philosophical perspective to discuss a vaccination rather than focused more on intellectual property

12 Noah Lewin-Epstein, Amit Kaplan \& Asaf Levanon, "Distributive Justice and Attitudes Towards the Welfare State" (2003) 16:1 Social Justice Research 1-44.

13 Fheriyal Sri Isriawaty, "Tanggung Jawab Negara Dalam Pemenuhan Hak Atas Kesehatan Masyarakat Berdasarkan Undang Undang Dasar Negara Republik Indonesia" (2015) 3:2 Jurnal Ilmu Hukum Legal Opinion 1-10.

14 Article 34 of the 1945 Constitution.

15 Harald Schmidt, "Vaccine Rationing and the Urgency of Social Justice in the Covid19 Response” (2020) 50:3 Hastings Center Report 46-49. 
rights. ${ }^{16}$ While the comparison is inevitable, the experience of other countries such as Israel, Norway, and India in COVID-19 vaccinations ${ }^{17}$ becomes the rationale to improve Indonesia's COVID-19 vaccination agenda. Amidst this discussion, it encourages the debate over the specific scope regarding independent vaccination in the light of human rights, distributive justice, and the welfare state. Then, this study adds an increasing insight into the Indonesian experience on COVID-19 vaccinations that represents other developing countries facing the same issue.

This study aimed to discuss the status quo of COVID-19 vaccinations in Indonesia based on existing regulations, following their practices. It elaborated aspects of COVID-19 vaccination under the government's control despite those open for private sector. Also, it examined the government's responsibility to ensure that COVID-19 vaccines are distributed equally in reflecting distributive justice by enquiring to what extent the government's policy on independent vaccination relates to the fulfillment of human rights. Finally, this study evaluated the current COVID-19 vaccination to reference Indonesia's handling of COVID-19 vaccines, which are essentially public goods.

\section{METHODS}

This study used a legal research method, which analyzed primary and secondary literature sources. This method examined rules, principles, and doctrines to address legal issues. ${ }^{18}$ The primary sources mainly consisted of laws and government regulations on COVID-19 vaccinations. The secondary sources consisted of legal doctrines and research from books, articles, news, research papers, and other relevant sources.

${ }^{16}$ Muh Ali Masnun, Eny Sulistyowati \& Irfa Ronaboyd, "Pelindungan Hukum Atas Vaksin Covid-19 Dan Tanggung Jawab Negara Pemenuhan Vaksin Dalam Mewujudukan Negara Kesejahteraan” (2021) 17:1 DiH: Jurnal Ilmu Hukum 35-47.

17 Bruce Rosen, Ruth Waitzberg \& Avi Israeli, "Israel's rapid rollout of vaccinations for COVID-19” (2021) 10:1 Israel Journal of Health Policy Research 1-14.

18 Theresia Anita Christiani, "Normative and Empirical Research Methods: Their Usefulness and Relevance in the Study of Law as an Object" (2015) 219:1 Procedia Social and Behavioral Sciences 201-207. 


\section{RESPONSIBILITY ON VACCINATION: SOCIAL JUSTICE AND WELFARE STATE PERSPECTIVES}

\section{A. An Overview of Distributive Justice and Welfare State}

According to Aristotle, distributive justice is a mechanism to distribute benefits and burdens among the members of a relevant group in proportion to some criterion for distribution, such as merit, needs, equality, and status. ${ }^{19}$ Rawls defines justice as fairness, which refers to the social contract coined by Locke, Rousseau, and Kant. ${ }^{20}$ Rawls also presents an idea called original position and veil of ignorance that corresponds to the idea of the state of nature in social contract theory. ${ }^{21}$ The main idea of the original position and the veil of ignorance is that the people do not know what they will become. They would not know where their place in society would become. They would not know their class position or social status, nor does anyone know their fortune in distributing natural assets and abilities, intelligence, strength, and the like. ${ }^{22}$ Thus, no one is advantaged or disadvantaged by natural chances. No one can impose the principles of justice just to favor a particular condition or act partially; the principles of justice result from a fair agreement. ${ }^{23}$ Through these two theories, Rawls tries to lead the community to obtain fair equality.

In the social contract theory based on the original position and the veil of ignorance, the subject (people) will use Rawls' two principles of justice or a so-called difference principle. ${ }^{24}$ The first principle is equal rights to get basic freedoms, including the freedom to do politics, freedom of expression, freedom from psychological oppression, and physical violence. ${ }^{25}$ The second principle is that forms of economic, social, and political differences and inequalities must be arranged to benefit the least disadvantaged of the society, and attached positions and offices open to all under conditions of

19 Tsachi Keren-Paz, Torts, Egalitarianism and Distributive Justice (London: Routledge, 2007).

${ }^{20}$ John Rawls, A Theory of Justice (Massachusetts: Harvard University Press, 1971).

21 Ibid.

22 Ibid.

23 Ibid.

${ }^{24}$ Ibid.

${ }^{25}$ Ibid. 
fair equality of opportunity. ${ }^{26}$ This principle requires citizens' same opportunity by providing facilities and opportunities to avoid inequality from the beginning, such as being born from a rich or poor class and other conditions. While there is a conflict between the first principle and the second principle, the first principle must be prioritized over the second. Thus, freedom of basic rights must be positioned as the highest value followed by equal opportunities for everyone. ${ }^{27}$

Nevertheless, Indonesia is claimed to adopt the welfare state by referring to the fifth principle stated in Pancasila - the basic guidelines of the Indonesian government. This principle states social justice for all Indonesian people, ${ }^{28}$ despite the preamble and articles of the 1945 Constitution to reiterate and specifically extend this principle. ${ }^{29}$ The basic formulation of the welfare state's ideology earlier-advancing the general welfare and the fifth principle of the Pancasila-was then manifested in the body of the Indonesian Constitution as a guideline for national life and state administration. ${ }^{30}$ Rawls puts social justice forward. He related matters where both of them want an economic system and justice into a balanced point between the role of the state and individuals, rights and obligations, and the fulfillment of civil, political, and economic socio-cultural rights. ${ }^{31}$ Thus, Indonesia must fully fulfill the rights of its citizens under social justice in Pancasila.

26 Ibid.

27 Ibid.

28 Social justice is economic justice or economic welfare or equality in the economic field that can only be achieved through the Indonesian socialism system. Indonesian socialism upholds the principles of equality and individual freedom, but individuals are always cooperative with an altruist attitude that promotes social solidarity. Yudi Latif, Negara Paripurna: Historisitas, Rasionalitas, dan Aktualitas Pancasila (Jakarta: Gramedia, 2005).

29 Preamble of the 1945 Constitution provides the basis that Indonesia is a welfare state. Another basis in recognizing human rights is in Chapter XA of the 1945 Constitution. Oman Sukmana, "Konsep dan Desain Negara Kesejahteraan (Welfare State)" (2016) 2:1 Jurnal Sospol 103-122.

30 A Alfitri, "Ideologi Welfare State Dalam Dasar Negara Indonesia: Analisis Putusan Mahkamah Konstitusi Terkait Sistem Jaminan Sosial Nasional” (2012) 9:3 Jurnal Konstitusi 449-472.

31 Yudi Latif, supra note 28. 
The purpose of welfare is to fulfill civil rights, including social services, to ensure that every citizen gets a minimum income. ${ }^{32}$ Thus, the welfare state is associated with the fulfillment of basic needs. It is considered as a mechanism of equalization of inequality caused by the market economy. According to Andersen, as quoted by Yohanes, the welfare state demands the state to have an active and responsible role in ensuring basic welfare services at a certain level for its citizens. ${ }^{33}$

There are four main pillars in a welfare state. They are social citizenship, full democracy, modern industrial relation system, rights to education, and the expansion of modern mass education systems. ${ }^{34}$ These pillars constitute the social rights of citizens, cannot be violated and given on the basis of citizenship, not performance or class. ${ }^{35}$ Thus, the Indonesian government must fulfill citizen rights by providing social services and ensuring a minimum income.

Various aspects ranging from social security, health, housing, and education are the main work areas of government policies that adhere to the welfare state. ${ }^{36}$ The forms of social security include health insurance, health services, employment insurance, retirement funds, fulfillment of basic needs, and others. Consequently, these fulfillments assert the right to get special facilities and treatment to get the same opportunities and benefits to achieve equality and justice as outlined under Articles 34 and $28 \mathrm{H}$ of the 1945 Constitution. Thus, it reflects Indonesia to adherence to the welfare state with a minimal model. ${ }^{37}$ In addition, the state is also expected to manage

32 Jørgen Goul Andersen, Welfare States and Welfare State Theory (Aalborg: Centre for Comparative Welfare Studies, Department of Political Science, Aalborg University, 2012).

33 Yohanes Suhardin, "Peranan Negara dan Hukum Dalam Memberantas Kemiskinan Dengan Mewujudkan Kesejahteraan Umum” (2012) 42:3 Jurnal Hukum \& Pembangunan 302-317.

34 Ibid.

35 Ibid.

36 Alfitri, supra note 30.

37 The minimal model is a model characterized by small government spending in the social development sector. Social security and welfare programs are provided sporadically, partially, and minimally. Social security is provided to civil servants and private employees who can pay. Suharto, supra note 10. 
natural resources wealth and use it for the citizen welfare and put it in a sustainable welfare framework under Article 33 of the 1945 Constitution. ${ }^{38}$ In essence, as a welfare state, Indonesia must make citizens prosperous by fulfilling citizens' basic needs as human rights. The legal frameworks that support the realization of the welfare state are Social Welfare Law 11/2009 and National Social Security System Law 40/2004.

\section{B. Independent Vaccines and Vulnerable Groups: A Quest for Social Justice and Welfare State}

The national solidarity to eradicate COVID-19 proves that the right to health is embedded in the idea of universal health coverage under public interest globally. Indeed, Indonesia is a welfare state, so that every citizen has the right to health. Indonesia's government must provide access to health and health services for its citizens affected by COVID-19. In this case, COVID-19 vaccines must be provided to all citizens due to fulfilling the right to health. Otherwise, the vaccine therapeutics and diagnostics must be made available on the general knowledge of equality and affordable accessibility for everyone, particularly at-risk groups. ${ }^{39}$ The $74^{\text {th }}$ session of the UN General Assembly concluded that COVID-19 vaccines should be promoted. ${ }^{40}$ It ensured fair, transparent, equitable, efficient, and timely access distribution, alongside medical tools and drugs. It is needed to fight the pandemic as equitable access to health products is a global concern, and the highest attainable standard of health is the right of every human being. ${ }^{41}$ It is relevant to Minister of Health Regulation 28/2020 on the implementation of vaccine procurement in the context of COVID-19

38 Yudi Latif, supra note 28.

39 World Health Organization, "WHO Director-General's speech at the Paris Peace Forum Panel: ACT-A: Covid-19 Vaccines, Tests and Therapies, the Global public good Solution - November 12, 2020", (2020), online: <https://www.who.int/directorgeneral/speeches/detail/who-director-general-s-speech-at-the-paris-peace-forumpanel-act-a-covid-19-vaccines-tests-and-therapies-the-global-public-good-solution--12-november-2020>.

40 United Nations General Assembly on International cooperation ensures global access to medicines, vaccines, and medical equipment to face COVID-19 (April 20, 2020).

41 Ibid. 
pandemic response. ${ }^{42}$ It enumerates that the procurement of the COVID19 vaccines aims to meet the vaccine availability to handle the pandemic. ${ }^{43}$

Vaccination as a countermeasure against the pandemic is rooted in Article $28 \mathrm{H}(1)$ of the 1945 Constitution. This article states that everyone has the right to live in physical and spiritual prosperity, to have a place to live and to have a good and healthy living environment, and the right to obtain health services. It becomes the basis of the right to vaccines as part of the right to health. In the meantime, Article $28 \mathrm{H}(2)$ emphasizes that everyone has the right to get special facilities and treatment to get the same opportunities and benefits to achieve equality and justice. It indicates that the fulfillment of the right to health must be carried out fairly and equitably to get benefits, as the implementation of the vaccination. Finally, Article 34(3) accounts for the state's responsibility to provide adequate health service facilities.

As the provisions are prepared to meet the availability of the vaccines in responding to the pandemic, ${ }^{44}$ the acceleration of vaccination should be made once the Indonesian government had already excessed vaccine availability. ${ }^{45}$ In other words, the vaccination should be given to those who are more vulnerable to the virus or priority groups. Under the difference principle as coined by Rawls, ${ }^{46}$ those vulnerable and unable to access vaccines should have an equal position by being given access to the vaccine first. Therefore, those who are vulnerable and do not have access to vaccines should be assisted by the government to access these vaccines. In addition, given social justice and the welfare state, vaccines understood as the right to health should be provided free of charge by the government to fulfill the right to health. It considers Indonesia must actively provide and fulfill the basic needs of citizens, which in this case are COVID-19 vaccines, ${ }^{47}$ to reflect the welfare state. To be sure, commercializing vaccines violates the right to health, and it negates the welfare state.

42 It was then amended to Minister of Health Regulation 79/2020.

43 Article 3 of the Minister of Health Regulation 28/2020.

44 Article 3(1) of the Minister of Health Regulation 28/2020.

45 Article 8(1) of the Minister of Health Regulation 10/2021.

46 Rawls, supra note 20.

47 Andersen, supra note 32. 
A policy that does not prioritize vulnerable groups is also not consistent with Article $28 \mathrm{H}$ (3) of the 1945 Constitution. This article outlines that everyone has the right to get special facilities and treatment to get the same opportunities and benefits to achieve equality and justice. The measure that discriminates the vulnerable groups results in discrimination and economic inequality. It should not be a condition where only some citizens with a certain class of economy and those who have the privilege can get vaccinated. Vulnerable citizens and those with low economic capacity should obtain access to a fair and just vaccination. Therefore, the vaccination should be implemented based on the principles of justice, non-discrimination, equality, free of charge, and under the vaccination phases for those who are vulnerable.

\section{Vaccines as Global Public Goods for Herd Immunity in Indonesia}

A welfare state must prove that citizens' rights of basic needs are in the hands of the state's responsibility. It is considered an equalization mechanism against the inequality created by the free market in the economy. ${ }^{48}$ While the right to health is part of public service, it urges vaccines to be considered global public goods, not private commodities. ${ }^{49}$ It is different from private goods. Public goods rely on the perspective of the degree to which they generate spillover effects-the effect of possible interaction of the nontarget group that could be affected by the treatment of the specific target group interaction through social and economic treatment ${ }^{50}$ - or externalities when consumed. ${ }^{51}$ Public goods have to fulfill the requirement of non-rivalrous and non-exclusive, where the marginal cost of the service to an additional user is zero, and the benefits from the goods are available to everyone as

48 Suhardin, supra note 33.

49 World Health Organization, supra note 39.

50 Manuela Angelucci \& Vincenzo Di Maro, "Program Evaluation and Spillover Effects: Impact-Evaluation Guidelines" (2010) May Inter-American Development Bank: Technical Notes 1-38.

51 WHO Commission on Macroeconomics and Health Working Group 2 \& World Health Organization, "Global public goods for health: the report of Working Group 2 of the Commission on Macroeconomics and Health" (2002) World Health Organization. 
nobody can be excluded from consumption once the goods are given. ${ }^{52}$ Thus, the government must interfere by providing goods and services marked by mutual gains. As vaccines become an indispensable commodity in the face of the pandemic, the lack of market efficiency would not become a problem with how the citizens must rely on the government to provide the vaccine.

While vaccines are deemed global public goods, to be sure, an urgency for government control on their distribution becomes inevitable. Vaccines as public goods answer questions about equity and the importance of the society and its impact on the agenda for health, ${ }^{53}$ especially under the right to health as a basic right that the government must provide. This agenda is vital as vaccines play a pivotal role in eradicating the current pandemic. Regardless of economic, social, and political differences, vaccines are accessible to all under fair equality of opportunity. The mass distribution of vaccines as public goods, consistent with distributive justice, can achieve herd immunity to counter COVID-19.

\section{COVID-19 VACCINATIONS IN INDONESIA}

The Indonesian legislation obliges the government to countermeasure plagues under Plague Law 05/1984. It can be accomplished through prevention and immunization. ${ }^{54}$ With regard to COVID-19, providing vaccines is indispensable. By definition, a vaccine is an organic agent that evokes a response of the immune system to a particular antigen acquired from an infectious pathogen. ${ }^{55} \mathrm{It}$ is commonly agreed that the only way to end this pandemic is to fulfill the need for a global universal vaccination in the scientific community. ${ }^{56}$ Given that COVID-19 is a plague of infectious disease, the government must carry out a vaccination. Then, the government

52 Laura Razzolini, "Public Goods" (2003) The Encyclopedia of Public Choice 782-784.

53 WHO Commission on Macroeconomics and Health. Working Group 2 \& World Health Organization, supra note 51.

54 Article 4 of the Plague Law 05/1984.

55 Jennifer Czochor \& Audrey Turchick, "Focus: Vaccine Introduction” (2014) 87:4 Yale Journal of Biology and Medicine 401-402.

56 Muhammad Yunus, Cam Donaldson \& Jean Luc Perron, "COVID-19 Vaccines A Global Common Good” (2020) 1:1 The Lancet Healthy Longevity 6-8. 
controls vaccines' procurement and implementation. In existing regulations, the procurement of vaccines is under the government's control, and the implementation of vaccination is divided into two schemes. The first is the vaccination program entirely under government control, following Minister of Health Regulation 10/2021. The second is the Gotong Royong vaccination accessible for corporations, including private institutions, to administer independently.

\section{A. The Vaccination Program in Planning and Procurement}

One of the aspects of the vaccination program under government control is the procurement of vaccines. The procurement of vaccines consists of providing vaccines, ancillary equipment, and all necessary logistics and the downstream distribution of vaccines. ${ }^{57}$ Through the Minister of Health, the government can determine the types and amount of vaccines needed in the procurement. ${ }^{58}$ The purpose of the procurement of vaccines is to fulfill the national need following the national vaccine requirement plan that the Minister of Health also determines. ${ }^{59}$ The government's control is manifested through the assignment of state-owned enterprises. ${ }^{60}$ The assignment of state-owned enterprises is because of enterprises' function to carry out public benefits. The Minister authorizes Bio Farma company as one of the state-owned enterprises obliged to carry out public benefits. ${ }^{61}$ The procurement is executed through collaboration with international institutions. ${ }^{62}$ This collaboration comprises the research and development of vaccines, excluding the ancillary equipment needed. ${ }^{63}$ By referring to the

57 Article 3 of the Presidential Regulation 99/2020 on the procurement of vaccines and execution of vaccination for COVID-19 pandemic response as amended with Presidential Regulation 14/2021.

58 Ibid, Article 2.

59 Article 6 of the Minister of Health Regulation 10/2021 on the execution of vaccination for COVID-19 pandemic response.

${ }^{60}$ Article 4 of the Presidential Regulation 99/2020.

${ }^{61}$ Muhammad Insa Ansari, "Penugasan Pemerintah pada Badan Usaha Milik Negara Sektor Ketenagalistrikan Dalam Perspektif Hukum Korporasi” (2018) 4:3 PADJADJARAN Jurnal Ilmu Hukum (Journal of Law) 551-568.

62 Article 4 of Presidential Regulation 99/2020.

63 Ibid. 
welfare state, the government is wholly responsible for procuring the vaccines as a commodity that is needed for the right to the public's health.

Another aspect of the vaccination under government control is the execution of vaccination. Minister of Health Regulation 10/2021 stipulates that the central government has the main power for executing vaccination. ${ }^{64}$ General aspects of executing vaccination under the government's full control include planning needs and targets of vaccination, distributing vaccines, ancillary pieces of equipment, logistics, collaborating on the execution of vaccination, and the registration and report of vaccination. ${ }^{65}$ The government's planning of vaccines is essential to proceed effectively and reach $67 \%$ of the population. ${ }^{66}$ This target is under the scientific consensus that recommends COVID-19 vaccinations to target $55 \%-82 \%$ of the population to develop herd immunity. ${ }^{67}$

There is no detailed description that herd immunity is a particular threshold proportion of immune individuals that should lead to a decline in the incidence of infection, or others refer to it as a pattern of immunity that should protect a population from an invasion of a new infection. ${ }^{68}$ It emphasizes the increase of individual immunity to affect pathogen transmission dynamics and the success of vaccination campaigns for entire host populations for the population-scale immunity. ${ }^{69}$ Herd immunity threshold is determined by mathematical models that can differentiate from varieties of infectious agents and the geography of the places. In general, herd

${ }^{64}$ Article 3 of the Minister of Health Regulation 10/2021.

65 Ibid, Article 5.

66 Office of Assistant to Deputy Cabinet Secretary for State Documents \& Translation, "Data of COVID-19 Vaccine Recipients Collected through Integrated Information System”, (2020), online: <https://setkab.go.id/en/data-of-covid-19-vaccinerecipients-collected-through-integrated-information-system $>$.

67 Sarah Schaffer Deroo, Natalie J Pudalov \& Linda Y Fu, "Planning for a COVID-19 Vaccination Program" (2020) 323:24 JAMA - Journal of the American Medical Association 2458-2459.

68 Paul Fine, Ken Eames \& David L Heymann, "Herd immunity: A rough guide" (2011) 52:7 Clinical Infectious Diseases 911-916.

69 Michael AB Naafs, "Herd Immunity: A Realistic Target?" (2018) 9:2 Biomedical Journal of Scientific \& Technical Research 1-5. 
immunity can only be achieved if it covers $55-82 \%$ of the population. ${ }^{70}$ Therefore, this population-based effort for herd immunity refers to the principle of equality that reflects the welfare state. Vaccines that will be distributed as public goods will be accomplished through a balance by the state's role for the rights of the individuals under the right to health.

Given a possible risk of short-term immunity with the newly emerging COVID-19 virus, the extent of reinfection and its consequences for human and population immunity is not yet understood. These observations are consistent with the general image of incomplete or temporary immunity to the newer virus. Certain newer virus variants will also restrict the potency and length of immunity conferred by a primary emerging virus infection, limiting the level of defense in individuals and populations. ${ }^{71}$ The eradication of COVID-19 would only be feasible if vaccines, with high effectiveness and protection and large distribution, will keep populations above the herd immunity threshold. Herd immunity influences the infection in the population to protect each person immunized. It also prevents the transmission of infection to others. There is a necessity for the vaccination to be done on the vulnerable group first. It is essential to map them out to prioritize the vaccination upon them first. Though there is no set criterion for developing the disease, it can be calculated which groups are at greater risk. It includes those in older age groups, minorities by racial and social category, including ethnic minorities, low-income groups, or those with underlying health problems, such as diabetes, obesity, or other medical therapies. ${ }^{72}$ Therefore, the government is responsible for ensuring basic human rights and welfare services to the more susceptible persons to get the same opportunity for being facilitated first.

Accordingly, Minister of Health Regulation 10/2021 has set priority groups for the COVID-19 vaccine recipients. COVID-19 vaccines are prioritized for workers at the forefront of COVID-19 pandemic response, elderly

70 Steven Sanche, et al., "High Contagiousness and Rapid Spread of Severe Acute Respiratory Syndrome Coronavirus 2" (2020) 26:7 Emerging Infectious Diseases 1470-1477.

71 Ibid.

72 Public Health England, Disparities in the risk and outcomes of COVID-19 (2020). 
citizens, public officers, and vulnerable groups in geospatial, social, and economy, and other members of the society. ${ }^{73}$ Those within the priority groups are set to receive COVID-19 vaccines consecutively. This policy is in line with the consideration that vaccines have to be distributed under social justice. ${ }^{74}$ The setting of priority groups aims to maximize the benefits of vaccination.

Although the priority groups of early vaccination are already stipulated in the law, the Minister can amend the criteria for the priority group of recipients of COVID-19 vaccines. It is made after observing the recommendation from the Indonesian Technical Advisory Group on Immunization and the considerations of the Committee for Handling COVID-19 and National Economic Recovery. ${ }^{75}$ Therefore, there is vagueness, and no certainty of the priority groups getting the vaccine as the Minister can change it at any time.

\section{B. The Gotong Royong Vaccination Scheme: Proposals and Challenges}

Whereas most aspects of the COVID-19 vaccination are in the government's full control, current regulations provide private sector opportunities for administering the vaccination. In the context of health service, private sector engagement (PSE) is a purposeful, systematic collaboration between the government and private sector to develop national health services forward beyond independent policies and programs. ${ }^{76}$ Private sector engagement aims to upgrade the quality of health services and broaden the reach of health accesses. ${ }^{77}$ In the context of COVID-19 vaccinations, private sector engagement may also be applied.

Minister of Health Regulation 10/2021 offers the opportunity for the private sector to administer vaccination through the independent scheme called the Gotong Royong vaccination. It is the scheme for employees and their

73 Article 8 of the Minister of Health Regulation 10/2021.

74 Harald-Schmidt, supra note 11.

75 Article 8 of the Minister of Health Regulation 10/2021.

${ }^{76} \mathrm{WHO}$, Engagement of private/nongovernmental health providers in immunization service delivery (Geneva: World Health Organization, 2017).

77 Ibid. 
families, including individuals financed by corporations. ${ }^{78}$ The independent vaccination aims to accelerate the completion of the national vaccination program. It is open for corporations that are financially capable of executing the vaccination at their own expense, including the purchase of vaccines from the government. ${ }^{79}$ Nevertheless, the individual recipients of vaccination are not charged with any fee. ${ }^{80}$ There are a few conditions in the administration of the Gotong Royong vaccination. The types of vaccines administered for said vaccination services have to be different from those used for the vaccination. ${ }^{81}$ Gotong Royong vaccination services can only be administered in private health facilities apart from the ones used for the vaccination program. ${ }^{82}$ In contrast, it does not conform with the welfare state. The Gotong Royong vaccination stipulated in the Ministry of Health regulation widens the chance of private Indonesian or foreign companies to fulfill the supply, ${ }^{83}$ given the number of targets both for the vaccination program and Gotong Royong vaccination. ${ }^{84}$ The payment is imposed on the legal entity that buys the vaccine and uses it for employees. ${ }^{85}$

At a glance, it looks fine. However, it can result in systemic discrimination for other legal entities incapable of paying for their employees' vaccination. Also, it can result in disparities that imply that the poor cannot help themselves. There is no further information on the mechanism to deal with that problem. The regulation itself does not specify many details on the system, which will be the factor for the recipients of the Gotong Royong vaccine, as mentioned in the previous parts.

To address COVID-19, the government applies vaccines and avoiding transmission between infectious and vulnerable individuals by non-

78 Ibid.

79 Ratih Waseso, "Jubir Vaksinasi Covid-19 sebut vaksinasi gotong royong tak dapat subsidi”, (2021), online: Kontan.co.id <https://nasional.kontan.co.id/news/jubirvaksinasi-covid-19-sebut-vaksinasi-gotong-royong-tak-dapat-subsidi>.

80 Article 1 of the Minister of Health Regulation 10/2021.

81 Ibid, Article 7.

82 Ibid, Article 22.

${ }^{83}$ Ibid, Article 1.

${ }^{84}$ Ibid, Article 6.

85 Ibid. 
pharmaceutical treatments. ${ }^{86}$ When infected and vulnerable individuals are not homogeneously blended, the herd immunity threshold for the entire population is smaller than under homogeneous mixing. One illustrative analysis of variable interaction rates within and between citizens in various age groups shows how a herd immunity threshold of 60 percent could be lowered to 44 percent. ${ }^{87}$ In epidemiology, the more significant fraction of immune individuals results in the smaller the risk of the infection outbreak. Citizens acquiring immunity to infection are covered directly and are also prohibited from spreading the infection to others. ${ }^{88}$

The independent vaccination policy lacks the guarantee of citizens' rights under the welfare state. To have effective herd immunity, a proper pharmaceutical approach includes a vaccine becomes essential. Therefore, the proper and just distribution of the vaccine is indispensable to avoid the exponent spread and infection against the healthcare system. ${ }^{89}$ So too, public communication regarding COVID-19 is also vital to urge a better system to implement the vaccination.

\section{COVID-19 VACCINATIONS IN OTHER COUNTRIES}

COVID-19 vaccinations are not only carried out in Indonesia but also worldwide. Some countries use a public vaccination scheme. Some also use a public vaccination scheme in collaboration with the private sector..$^{90}$ Countries that use the full public vaccination scheme are Israel, Bhutan, Sweden, Norway, Denmark, and other Scandinavian countries. Meanwhile, countries that use public-private vaccination schemes are Indonesia and India. This section will compare how public vaccination and public-private

86 The Royal Society, "Herd immunity in the epidemiology and control of COVID-19".

87 Tom Britton, Frank Ball \& Pieter Trapman, "A mathematical model reveals the influence of population heterogeneity on herd immunity to SARS-CoV-2" (2020) 369:6505 Science 846-849.

88 The Royal Society, supra note 86.

89 Sanche, et al, supra note 70.

90 This scheme means that the COVID-19 vaccination program collaborates with private parties such as companies to provide vaccines to citizens. This can be seen from the cooperation vaccination scheme in Indonesia, but not all vaccines are free of charge to citizens. 
vaccination are carried out in other countries relevant to the Indonesian context. Then, it will describe and analyze which system is better and should be implemented in carrying out COVID-19 vaccinations. As previously reported, Israel, Bhutan, Sweden, Norway, Denmark, and other Scandinavian countries use a public vaccination system. This study considers Israel and Norway that are success in implementing public vaccination system. Also, it exemplifies India that has good system in applying the division of COVID-19 private sectors.

\section{A. Israeli Vaccination Policy}

Israel is a country that adheres to the welfare state. ${ }^{91}$ It refers to the Israeli policies that provide subsidies to education, health, and social welfaresocial security. ${ }^{92}$ This Israeli welfare state is a universal model mainly consisting of social insurance programs. The primary source of insurance comes from countries managed by the National Insurance Institution, ${ }^{93}$ and Israel defines welfare states through the vaccination program. Israel has signed contracts with many pharmaceutical companies to produce COVID19 vaccines. ${ }^{94}$ Israel started COVID-19 vaccinations on December 20, $2020 .{ }^{95}$ As of May 2020, there had been 5 million citizens fully vaccinated. ${ }^{96}$ About 62.8 percent of citizens received the first dose of COVID-19 vaccines. ${ }^{97}$ Meanwhile, 58.9 percent or more than half of citizens had been fully vaccinated in the second dose of vaccine..$^{98}$ Israel has undergone the fastest in vaccinating, placing it as the successful country to implement COVID-19 vaccinations.

91 John Gal, "Immigration and the categorical welfare state in Israel" (2008) 82:4 Social Service Review 639-661.

92 John Gal \& Shavit Madhala, John Gal and Shavit Madhala, Israel's Social Welfare System: An Overview (Jerusalem: Taub Center, 2018).

93 John Gal, supra note 107 at 646.

94 Rosen, Waitzberg \& Israeli, supra note 17.

95 Ibid.

96 Our World in Data, "Coronavirus (COVID-19) Vaccinations", (2021), online: $<$ https://ourworldindata.org/covid-vaccinations?country= ISR $>$.

97 Ibid.

98 Ibid. 
Initial targets for vaccine recipients are citizens aged 60 years and older, residents of nursing homes, health workers, and citizens with severe medical conditions-especially respiratory diseases. ${ }^{99}$ The main objective of this priority scheme is to reduce the death and severe illness associated with COVID-19, particularly for vulnerable groups. The other goal is that the vulnerable community has been vaccinated to open up economic activities without risking health risks to the community. ${ }^{100}$ In addition, vaccinating vulnerable groups and health workers will not burden the health system.

This success can be achieved due to several factors ranging from the centralized government system, organizational system, technology, and logistics of the four large-scale and national Israeli Health Institutions to the simple, broad, and clear criteria in determining the priority of vaccine recipients. ${ }^{101}$ The first factor is that Israel is a centralized country. The regions in Israel do not have the authority to deal with public health. There is no need for excessive coordination to take policies related to public health despite providing assurance and clarity in implementing vaccination. ${ }^{102}$ The next factor concerns the implementation of COVID-19 vaccinations by the four Israeli Health Institutions. Vaccination in Israel is carried out in full by the government with the help of four Israeli Health Agencies ${ }^{103}$ that provide free national health insurance. ${ }^{104}$ All citizens have the right to get free national health insurance as the government's obligations under National Health Insurance Act. ${ }^{105}$ This Act states that health insurance must be based on the principles of justice, equality, and mutual assistance. The four

99 Ibid, at 9 .

${ }^{100}$ Ibid.

${ }^{101} \mathrm{Ibid}$, at 3-4.

${ }^{102} \mathrm{Ibid}$, at 5 .

${ }^{103}$ The four Israeli Health Institutions are Kupat Holim Clalit, Kupat Holim Maccabi, Kupat Holim Leumit, and Kupat Holim Meuhedet. Besides that, every Israeli citizen who registers with one of these Health Institutions must be registered. Ruth Waitzberg \& Bruce Rosen, "International Health Care System Profiles: Israel," (2020), online: The Commonwealth Fund <https://www.commonwealthfund.org/ international-health-policy-center/countries/israel>.

${ }^{104}$ All residents of Israel have the freedom to choose between the four major Health institutions, but what is interesting is that the Health Institute itself is non-profit. Lihat: Bruce Rosen, Ruth Waitzberg, and Avi Israeli, supra note 17 at 6.

${ }^{105}$ Ibid. 
institutions have been highly trained in administering vaccinations because they hold influenza vaccinations every year. Moreover, they also have medical records or patient data for epidemiological policymaking. ${ }^{106}$

\section{B. Norwegian Vaccination Policy}

Norway is another country that also applies a public vaccination system under the welfare state. The welfare state in Norway is universal, ${ }^{107}$ so that the vaccination is accomplished through the Norwegian Vaccination System. The central government has the primary role before it hands down to the local governments. The local governments carry out vaccinations to residents in their areas. ${ }^{108}$ In determining who should receive the vaccine, the Norwegian Health Institute determines that only vulnerable groups get priority vaccination first, including the elderly, vulnerable groups, and health workers. ${ }^{109}$ The vulnerable community is prioritized first due to limited vaccines. ${ }^{110}$ Also, this vaccination is entirely free. ${ }^{111} \mathrm{It}$ is different from the scheme in Indonesia, where someone through a company can get the vaccine in advance by paying for the vaccine. In addition, Norwegian citizens also have the right to determine what vaccine they want. Insofar, under the public vaccination scheme, Norway has given its first dose of vaccine to 1,5 million citizens. Meanwhile, the residents who received the second dose were 600 thousand citizens. ${ }^{112}$ Given that Norway's vaccination system prioritizes

\footnotetext{
${ }^{106}$ Bruce Rosen, Ruth Waitzberg, and Avi Israeli, supra note 17 at 6.

${ }^{107}$ Christiani, supra note 18.

${ }^{108}$ Norwegian Institute of Public Health, "Coronavirus vaccine - information for the public," (2020), online: <https://www.fhi.no/en/id/vaccines/coronavirusimmunisation-programme/coronavirus-vaccine/>.

${ }^{109}$ The priority for vaccine recipients starts from citizens aged over 85 years, aged 75-84 years, and aged 65-74 years. Some citizens have certain severe medical conditions such as diabetes, chronic lung disease, and down syndrome. Health workers are in the last rank, and vaccinations for the health workers are carried out in parallel with vulnerable groups. Norwegian Institute of Public Health, "Who will get the coronavirus vaccine?”, (2021), online: <https:/www.fhi.no/en/id/vaccines/ coronavirusimmunisation-programme/who-will-get-coronavirus-vaccine-first/>.

${ }^{110}$ Ibid.

${ }^{111}$ Ibid.

${ }^{112}$ Ibid.
} 
vulnerable groups, distributive justice becomes the main feature in supporting successful vaccination.

\section{Indian Vaccination Policy}

In comparison to Indonesia's policy on vaccination plans, India is one of the few countries that apply the division of COVID-19 private sectors. India's central government established the Indian national Covid-19 vaccination campaign. August 2020, under the chairmanship of VK Paul, member (health) of Niti Aayog, a task force called the National Expert Group on Vaccine Administration for COVID-19 was established to decide different aspects ranging from conceptualization to last-mile distribution. ${ }^{113}$ In January 2021, the Indian government began vaccinating healthcare and frontline workers. ${ }^{114}$ On March 1, 2021, vaccinations were extended to those above 60 years and those above 45 years with comorbidities, which then changes starting April 1, 2021. ${ }^{115}$ All above 45 years were eligible to be vaccinated. However, on May 1, 2021, the eligibility was lowered to aged 18, and that all citizens aged 18-44 in India have to register on the government's CoWin platform to get vaccinated. ${ }^{116}$

The central government has the sole authority to purchase and administer vaccines before the new regulation's implementation in May 2021. The central government was paying INR 150 per dosage, exclusive of GST, for Serum Institute and Bharat Biotech vaccines. ${ }^{117}$ In government hospitals, the vaccines were free, while private hospitals charged INR 250 per dosage. The hospital kept INR 100 towards its costs of that fee, and the central government was given INR 150. However, after May 2021, private hospitals and other private entities can also purchase vaccines in the open market and

\footnotetext{
${ }^{113}$ Bloomberg, "The Who, What, When Of Vaccination In India: BQExplains," (2021), online: <https://www.bloombergquint.com/coronavirus-outbreak/indias-covidvaccine-policy-all-you-need-to-know $>$.

${ }^{114}$ Cowin, "CoWin, online <https://www.cowin.gov.in>", online: CoWin <https:// www.cowin.gov.in>.

${ }^{115}$ Ibid.

${ }^{116}$ Ibid.

${ }^{117}$ Bloomberg, supra note 113.
} 
provide vaccinations. The new vaccine policy allows states and private entities also to procure and distribute vaccines. From them, Serum Institute and Bharat Biotech are charging a higher price. ${ }^{118}$

India's Covid Vaccination Center (CVC) released the Liberalized Pricing and Accelerated National COVID-19 Vaccination. The center said that every month 50 percent of the total Central Drugs Laboratory (CDL)cleared vaccine doses would be procured by the government of India, which will be made available to the states free of cost, as was being done earlier. ${ }^{119}$ Out of the $50 \%$ non-government of India quota, half will go to the state governments and the other half to the private sector. ${ }^{120}$ As stated in the Health Ministry's affidavit filed in the Supreme Court, the reasoning is that 25 percent of vaccination through the private sector will encourage improved access and minimize the operational burden on government vaccination facilities. ${ }^{121}$

As a result, a veritable free market for vaccines has been developed and manufactured with public and private funding. At private hospitals, a single dose can now cost up to INR 1,500. Some opposition parties have said the federal government had abdicated its responsibility, opening up debilitating competition among states. States would spend twice as much for a dosage of Covishield-USD 4-as the federal government does, and four times as much for Covaxin-USD 8. This came after the two corporations made a philanthropic effort by lowering premiums for governments. States are now vying for limited supplies with private clinics and will push the prices on to their patients. ${ }^{122}$ Consequently, the number of vaccinated citizens compared to the number of citizens who should be vaccinated is wide in the margin. As of May 18, 2021, the number of India's citizens vaccinated according to

\footnotetext{
${ }^{118}$ Ibid.

${ }^{119}$ Rema Nagarajan \& Shankar Raghuraman, "Covid-19: Very little of 25\% vaccination quota for private hospitals flowing to rural India", (2021), online: The Times of India $<$ https://timesofindia.indiatimes.com/india/very-little-of-25-vaccination-quota-forprivate-hospitals-flowing-to-rural-india/articleshow/82722965.cms $>$.

${ }^{120}$ Ibid.

${ }^{121}$ Ibid.

122 Nikhil Inamdar \& Aparna Alluri, "How India's vaccine drive went horribly wrong," (2021), online: BBC Nerws <https://www.bbc.com/news/world-asia-india-57007004>.
} 
Our World in Data is only 10,45 percent. ${ }^{123}$ Only about 145 million citizens have been vaccinated bound to receive the service. ${ }^{124}$ It proves how the market prices concerning the Indian policy open up to the private sectors for vaccine procurement.

From this comparison, the public vaccination scheme is very much under the welfare state and distributive justice. It fulfills the right to public health by providing full and free vaccines to its citizens, and the country prioritizes vaccination for vulnerable citizens. This is different from the private scheme, which does not provide free vaccines and does not prioritize vaccinations for vulnerable citizens.

\section{CONCLUSION}

The Gotong Royong vaccination scheme is incompatible with distributive justice and the welfare state. Gotong Royong vaccination results in injustice, discrimination, and economic inequality because it only provides certain privileged citizens access to vaccines. The government should provide vaccines free of charge to fulfill access and rights to public health, particularly for vulnerable groups. Meanwhile, Gotong Royong vaccination does not have priority, ignoring vulnerable groups from the virus. It contradicts the welfare state and distributive justice because the welfare state is measured from whether the state has fulfilled the rights to the health of citizens by providing vaccines in full and for free. Also, the indicator for the fulfillment of distributive justice is whether the state prioritizes vulnerable groups to get vaccines rather than giving vaccines to citizens who are not at significant risk. Compared to other countries such as Israel, Norway, and India, the public vaccination scheme in Indonesia remains under the welfare state and distributive justice. However, it is different from the private scheme, which does not provide free vaccines and does not prioritize vaccinations for vulnerable groups. Therefore, the Indonesian government should amend the vaccination policy to focus more on the public vaccination scheme.

123 Our World in Data, "Coronavirus (COVID-19) Vaccinations", (2021), online: $<$ https://ourworldindata.org/covid-vaccinations?country= IND>.

${ }^{124}$ Ibid. 


\section{ACKNOWLEDGMENTS}

None.

\section{COMPETING INTEREST}

The authors declared that they have no competing interests.

\section{REFERENCES}

Aisyah, Dewi Nur, et al., "A spatial-temporal description of the SARSCoV-2 infections in Indonesia during the first six months of the outbreak" (2020) 15:12 PLOS ONE 1-14.

Alfitri, A, "Ideologi Welfare State Dalam Dasar Negara Indonesia: Analisis Putusan Mahkamah Konstitusi Terkait Sistem Jaminan Sosial Nasional” (2012) 9:3 Jurnal Konstitusi 449-472.

Andersen, Jørgen Goul, Welfare States and Welfare State Theory (Aalborg: Centre for Comparative Welfare Studies, Department of Political Science, Aalborg University, 2012).

Angelucci, Manuela \& Vincenzo Di Maro, "Program Evaluation and Spillover Effects: Impact-Evaluation Guidelines" (2010) May InterAmerican Development Bank: Technical Notes 1-38.

AB Naafs, Michael, "Herd Immunity: A Realistic Target?" (2018) 9:2 Biomedical Journal of Scientific \& Technical Research 1-5.

BBC News, "Covid: Vaccines running out in poorer nations, WHO says," online: <https://www.bbc.com/news/world-57558401>.

Britton, Tom, Frank Ball \& Pieter Trapman, "A mathematical model reveals the influence of population heterogeneity on herd immunity to SARSCoV-2" (2020) 369:6505 Science 846-849.

Bloomberg, "The Who, What, When Of Vaccination In India: BQ Explains," (2021), online: <https://www.bloombergquint.com/ coronavirus-outbreak/indias-covid-vaccine-policy-all-you-need-toknow>. 
Christiani, Theresia Anita, "Normative and Empirical Research Methods: Their Usefulness and Relevance in the Study of Law as an Object" (2015) 219:1 Procedia - Social and Behavioral Sciences 201-207.

Cowin, "CoWin, online <https://www.cowin.gov.in>”, online: CoWin $<$ https://www.cowin.gov.in>.

Czochor, Jennifer \& Audrey Turchick, "Focus: Vaccine Introduction" (2014) 87:4 Yale Journal of Biology and Medicine 401-402.

Djalante, Riyanti, et al., "Review and analysis of current responses to COVID-19 in Indonesia: Period of January to March 2020" (2020) 6:4 Progress in Disaster Science 1-9.

Fine, Paul, Ken Eames \& David L Heymann, "Herd immunity: A rough guide” (2011) 52:7 Clinical Infectious Diseases 911-916.

Gal, John, "Immigration and the categorical welfare state in Israel" (2008) 82:4 Social Service Review 639-661.

Gal, John \& Shavit Madhala, John Gal and Shavit Madhala, Israel's Social Welfare System: An Overview (Jerusalem: Taub Center, 2018).

Inamdar, Nikhil \& Aparna Alluri, "How India's vaccine drive went horribly wrong," (2021), online: BBC News <https://www.bbc.com/news/world -asia-india-57007004>.

Isriawaty, Fheriyal Sri, "Tanggung Jawab Negara Dalam Pemenuhan Hak Atas Kesehatan Masyarakat Berdasarkan Undang Undang Dasar Negara Republik Indonesia” (2015) 3:2 Jurnal Ilmu Hukum Legal Opinion 1-10.

Keren-Paz, Tsachi, Torts, Egalitarianism and Distributive Justice (London: Routledge, 2007).

Komite Penanganan COVID-19 dan Pemulihan Ekonomi Nasional, "Data Vaksinasi COVID-19 (Update 4 Maret 2021)”, (2021), online: $<$ https://covid19.go.id/p/berita/data-vaksinasi-covid-19-update-4maret-2021>.

Kuhnle, Stein \& Sven Hort, "The Developmental Welfare State in Scandinavia Lessons for the Developing World" (2004) 17 Social Policy and Development. 
Lewin-Epstein, Noah, Amit Kaplan \& Asaf Levanon, "Distributive Justice and Attitudes Towards the Welfare State" (2003) 16:1 Social Justice Research 1-44.

Masnun, Muh Ali, Eny Sulistyowati \& Irfa Ronaboyd, "Pelindungan Hukum Atas Vaksin Covid-19 Dan Tanggung Jawab Negara Pemenuhan Vaksin Dalam Mewujudukan Negara Kesejahteraan" (2021) 17:1 DiH: Jurnal Ilmu Hukum 35-47.

Muhammad Insa Ansari, "Penugasan Pemerintah pada Badan Usaha Milik Negara Sektor Ketenagalistrikan Dalam Perspektif Hukum Korporasi” (2018) 4:3 PADJADJARAN Jurnal Ilmu Hukum (Journal of Law) $551-568$.

Nagarajan, Rema \& Shankar Raghuraman, "Covid-19: Very little of 25\% vaccination quota for private hospitals flowing to rural India”, (2021), online: The Times of India <https://timesofindia.indiatimes.com/india/ very-little-of-25-vaccination-quota-for-private-hospitals-flowing-torural-india/articleshow/82722965.cms>.

Norwegian Institute of Public Health, "Coronavirus vaccine - information for the public", (2020), online: <https://www.fhi.no/en/id/vaccines/ coronavirus-immunisation-programme/coronavirus-vaccine/>.

_- "Who will get the coronavirus vaccine?", (2021), online: <https:// www.fhi.no/en/id/vaccines/coronavirus-immunisationprogramme/who-will-get-coronavirus-vaccine-first/>.

Office of Assistant to Deputy Cabinet Secretary for State Documents \& Translation, "Data of COVID-19 Vaccine Recipients Collected through Integrated Information System", (2020), online: <https:// setkab.go.id/en/data-of-covid-19-vaccine-recipients-collectedthrough-integrated-information-system $>$.

Our World in Data, "Coronavirus (COVID-19) Vaccinations", (2021), online: < https://ourworldindata.org/covid-vaccinations?country= ISR $>$.

Public Health England, Disparities in the risk and outcomes of COVID-19 (2020). 
Puspita, Ratna, "Kemenkes: Kondisi Geografis Tantangan Distribusi Vaksin”, (2021), online: Republika.co.id <https:/www.republika.co.id/ berita/qrut99428/kemenkes-kondisi-geografis-tantangan-distribusivaksin>.

Rawls, John, A Theory of Justice (Massachusetts: Harvard University Press, 1971).

Razzolini, Laura, "Public Goods" (2003) The Encyclopedia of Public Choice 782-784.

Rosen, Bruce, Ruth Waitzberg \& Avi Israeli, "Israel's rapid rollout of vaccinations for COVID-19" (2021) 10:1 Israel Journal of Health Policy Research 1-14.

Sanche, Steven, et al., "High Contagiousness and Rapid Spread of Severe Acute Respiratory Syndrome Coronavirus 2" (2020) 26:7 Emerging Infectious Diseases 1470-1477.

Sari, Haryanti Puspa, "UPDATE: Tambah 21.807 Orang, Kasus Covid-19 Indonesia Capai 2.178.272", (2021), online: Kompas.com $<$ https://nasional.kompas.com/read/2021/06/30/16203191/updatetambah-21807-orang-kasus-covid-19-indonesia-capai-2178272>.

Schaffer Deroo, Sarah, Natalie J Pudalov \& Linda Y Fu, "Planning for a COVID-19 Vaccination Program” (2020) 323:24 JAMA - Journal of the American Medical Association 2458-2459.

Schmidt, Harald, "Vaccine Rationing and the Urgency of Social Justice in the Covid-19 Response" (2020) 50:3 Hastings Center Report 46-49.

Sheikh, Abu Baker, et al., "COVID-19 vaccination in developing nations: Challenges and opportunities for innovation" (2021) 13:2 Infectious Disease Reports 429-436.

Strangio, Sebastian, "Jokowi Receives First Shot as Indonesia Begins CoronaVac Roll-out", (2021), online: The Diplomat <https:// thediplomat.com/2021/01/jokowi-receives-first-shot-as-indonesiabegins-coronavac-roll-out/>. 
Suhardin, Yohanes, "Peranan Negara dan Hukum Dalam Memberantas Kemiskinan Dengan Mewujudkan Kesejahteraan Umum” (2012) 42:3 Jurnal Hukum \& Pembangunan 302-317.

Suharto, Edi, "Peta Dan Dinamika Welfare State Di Beberapa Negara: Pelajaran Apa yang Bisa Dipetik untuk Membangun Indonesia?" (2006) 1-15.

Sukmana, Oman, "Konsep dan Desain Negara Kesejahteraan (Welfare State)" (2016) 2:1 Jurnal Sospol 103-122.

The Royal Society, "Herd immunity in the epidemiology and control of COVID-19”.

$\mathrm{WHO}$, Engagement of private/nongovernmental health providers in immunization service delivery (Geneva: World Health Organization, 2017).

WHO Commission on Macroeconomics and Health Working Group 2 \& World Health Organization, "Global public goods for health: the report of Working Group 2 of the Commission on Macroeconomics and Health" (2002) World Health Organization.

Yudi Latif, Negara Paripurna: Historisitas, Rasionalitas, dan Aktualitas Pancasila (Jakarta: Gramedia, 2005).

Yunus, Muhammad, Cam Donaldson \& Jean Luc Perron, "COVID-19 Vaccines A Global Common Good" (2020) 1:1 The Lancet Healthy Longevity 6-8.

- - "Coronavirus (COVID-19) Vaccinations", (2021), online: $<$ https://ourworldindata.org/covid-vaccinations?country= IND>.

Waitzberg, Ruth \& Bruce Rosen, "International Health Care System Profiles: Israel", (2020), online: The Commonwealth Fund <https:// www.commonwealthfund.org/international-health-policycenter/countries/israel>.

Waseso, Ratih, "Jubir Vaksinasi Covid-19 sebut vaksinasi gotong royong tak dapat subsidi”, (2021), online: Kontan.co.id <https://nasional. kontan.co.id/news/jubir-vaksinasi-covid-19-sebut-vaksinasi-gotongroyong-tak-dapat-subsidi>. 
World Health Organization, "WHO Director-General's speech at the Paris Peace Forum Panel: ACT-A: Covid-19 Vaccines, Tests and Therapies, the Global public good Solution - 12 November 2020", (2020), online: <https://www.who.int/director-general/speeches/ detail/who-directorgeneral-s-speech-at-the-paris-peace-forum-panel-act-a-covid-19vaccines-tests-and-therapies-the-global-public-good-solution---12november-2020>. 